\title{
Pemberitaan Berlebihan Tindakan Asusila, Moral Panic dan Copycat Crime: Kasus Prostitusi Online Artis
}

\author{
Guntur Freddy Prisanto \\ Sekolah Tinggi Manajemen Informatika dan Teknik Komputer (STIKOM) InterStudi \\ Email: guntur74@icloud.com
}

\begin{abstract}
Mass media coverage of the case of artists involved in online prostitution can be categorized to be excessive, both in terms of quantity and scope of talks. The audience was brought in to understand the character of the case so deeply through narrative reporting. This can have an impact on the emergence of moral panic, the reaction of the community that is disproportionate to the actions of people or groups, which are considered to deviate from the prevailing social and cultural values and norms. In addition, the exposure in such detailed news can encourage the act of copycat crime, the immoral act is imitated by the audience who have certain characteristics in common with the main characters in this news.
\end{abstract}

Keywords: reporting, moral panic, imitating evil

\begin{abstract}
Abstrak. Pemberitaan media massa tentang kasus artis yang terlibat prostitusi online dapat dikatakan berlebihan baik dari segi kuantitas maupun lingkup pembicaraan. Audiens dibawa masuk dalam pemahaman tokoh kasus ini dengan begitu dalam melalui pemberitaan yang naratif. Hal ini dapat berdampak pada munculnya kepanikan moral, yaitu reaksi masyarakat yang tidak proporsional terhadap tindakan orang atau kelompok, yang dianggap menyimpang dari nilai dan norma sosial serta budaya yang berlaku. Selain itu pemaparan dalam pemberitaan yang begitu rinci dapat mendorong terjadinya tindakan meniru kejahatan, yaitu tindak asusila tersebut ditiru oleh audiens yang memiliki kesamaan karakter tertentu dengan tokoh dalam pemberitaan ini.
\end{abstract}

Kata kunci: pemberitaan, kepanikan moral, meniru kejahatan

\section{Pendahuluan}

Awal tahun 2019, media massa ramai memberitakan penangkapan seorang artis (VA) dalam kasus prostitusi online. Drama demi drama berlanjut. Sang artis dalam pengakuannya merasa dijebak, karena semula diundang ke Surabaya untuk menjadi pembawa acara/ master of ceremony (detik.com, 6 Januari 2019).

Berdasarkan serangkaian pemeriksaan kepolisian, VA akhirnya ditahan sekitar sebulan sejak pertama terungkapnya kasus tersebut. Pasal yang disangkakan adalah Pasal 27 ayat 1 UU ITE, dimana yang bersangkutan menurut keterangan pihak kepolisian, dianggap berperan aktif mendistribusikan konten pornografi ke mucikari hingga menyebar ke pengguna prostitusi online (jatim.tribunnews.com, 7 Februari 2019).

Pemberitaan tentang prostitusi online di kalangan artis bukan sekali ini terjadi. Akhir tahun 2015 artis NM yang sedang berada di puncak popularitas, juga tertangkap basah di hotel Kempinski. Pelanggan adalah seorang polisi yang menyamar. Artis NM kemudian direhabilitasi di panti sosial untuk waktu yang singkat, kemudian dibebaskan kembali. NM tidak ditahan, karena dalam pespektif perdagangan 
orang, ia dipandang sebagai korban. Mucikari dalam peristiwa ini yang ditahan sebagai pelaku perdagangan orang.

Setelah itu pemberitaan terkait prostitusi di kalangan artis tidak beredar kembali, hingga tertangkapnya artis VA awal Januari 2019. Namun kali ini pemberitaan kasus ini terasa begitu luas dan intensif. Komentar dan pandangan pro kontra dari berbagai pihak mewarnai media massa. Ini meramaikan pemberitaan tentang kasus prostitusi online $\mathrm{VA}$.

Pemberitaan yang masif dalam berbagai media online tentang masalah ini, memunculkan pertanyaan tentang dampak yang ditimbulkan. Mengingat secara konseptual, pemberitaan di media massa tentang tindak asusila atapun kejahatan dapat menimbulkan kepanikan moral/ moral panic (Cohen, 1973 dalam Eriyanto, 2013), efek meniru kejahatan/ copycat (Surette, 2002), maupun takut akan kejahatan/ fear of crime (Kupchik dan Bracy, 2009). Untuk faktor takut akan kejahatan, pembahasannya lebih banyak dikaitkan dengan tindak pidana seperti pembunuhan, perampokan maupun pemerkosaan.

Atas dasar uraian di atas, maka penelitian ini hendak menjawab dua pertanyaan: (a) bagaimana dampak pemberitaan berlebihan tindak asusila prostitusi online dapat menimbulkan kepanikan moral? (b) bagaimana dampak pemberitaan berlebihan tindak asusila prostitusi online dapat menimbulkan peluang terjadinya peniru kejahatan?

\section{Kerangka Konseptual}

\section{Berita yang Bernilai}

Unsur-unsur tertentu meningkatkan nilai berita di mata publik. Dinyatakan Lawrence dan Mueller (2003), "cerita paling bernilai berita adalah yang dramatis dan sensasional, fokus pada individu-individu terkenal dan fitur konflik atau tindakan yang salah". Unsur-unsur lain yang membentuk nilai berita diantaranya bila melibatkan korban yang tidak bersalah, pelaku brutal, gangguan sosial dan mengandung gagasan bahwa keadilan akan menang (Lawrence \& Mueller, 2003; Glassner, 1999; Dowler, 2003; Sampert, 2010). Glassner (1999) serta Lawrence dan Mueller (2003), mengemukakan bahwa insiden yang layak diberitakan adalah peristiwa yang jarang terjadi, tetapi secara konsisten menerima liputan berita terbanyak (Wing, 2012).

Literatur menunjukkan bahwa media dalam upaya membangkitkan minat audiens, menerapkan teknik dan gaya pelaporan tertentu. Salah satu metode yang diungkapkan oleh Sampert (2010) menunjukkan bahwa media menyaring dan membangun kasus yang memperkuat kepercayaan yang dipegang banyak orang terkait jenis kelamin, ras, etnis, dan kelas sosial. Strategi lain pelaporan untuk membangkitkan minat audiens adalah melalui presentasi fisik. Glassner (1999) berpendapat bahwa walaupun peristiwa-peristiwa tertentu kemungkinan jarang terjadi, metode dimana media menyajikan berita, sangat mungkin mempengaruhi audiens (Wing, 2012).

Menurut Lawrence dan Mueller (2003), "gambar grafis tentang pembunuhan dan kekacauan" adalah salah satu strategi yang dilakukan media untuk mempengaruhi orang mengabaikan masalah sosial, politik dan psikologis yang mendasari perilaku kriminal (hal. 332). Melalui penggunaan bahasa yang dramatis, jurnalis dapat menggambarkan dan menyampaikan fakta sesuai diskresi mereka (Glassner, 1999; Livingston, 1994; Sampert, 2010; Lawrence \& Mueller, 2003). Seperti 
yang diperlihatkan dalam majalah Time edisi 1993, bahasa dan nada suara yang digunakan jurnalis berfungsi untuk meyakinkan pembaca bahwa Amerika tidak lagi aman. Glassner (1999) menyajikan beberapa frasa dari berbagai sumber media - "epidemi," "tidak ada yang aman," "jalanan penuh dengan kejahatan," dan "taman bermain penjahat." Frasa yang mirip dengan ini dianggap oleh banyak peneliti sebagai alat kuat yang digunakan oleh pembawa berita untuk menangkap dan meyakinkan pembaca mereka (Wing, 2012).

\section{Dampak dari Pemberitaan}

Karena sirkulasi dan produksi berbagai media secara konstan, audiens dibombardir berbagai fakta dan cerita. Mengukur sejauh mana banjir informasi ini berdampak pada publik, analisis Ruiz dan Treadwell (2002) terhadap materi cetak dan siaran menemukan bahwa efek negatif dapat dihasilkan dari fokus media yang konstan terhadap berita yang berorientasi pada kejahatan. Ruiz dan Treadwell berpendapat bahwa persepsi salah tentang kejahatan dipengaruhi oleh berita terkait kejahatan secara berlebihan di satu wilayah, sementara mengabaikan jenis berita lainnya. Altheide (2002) mengemukakan bahwa, dalam upaya untuk mempertahankan minat pemirsa, media memberi publik berbagai berita kriminal yang sensasional. Altheide lebih lanjut menyatakan bahwa penciptaan rasa takut adalah konsekuensi dari banjir informasi ini.

Altheide (2002), Ruiz dan Treadwell (2002) dan Glassner (1999) lebih lanjut menyatakan bahwa karena jumlah reportase berlebihan yang dipompa ke masyarakat, audiens mengembangkan persepsi yang salah. Mereka menganggap realitas serupa dengan yang dilihat dan didengar dalam berita, sehingga mendukung Teori Substitusi dan "mean-world syndrome" yang diajukan oleh Gerbner (2002), Weitzer dan Kubrin (2004), Smolej (2011), dan Glassner (1999). Ruiz dan Treadwell juga membahas fenomena ini sebagai kepanikan moral, di mana masyarakat mulai bereaksi berlebihan karena cara yang menyimpang dalam memandang dunia (Wing, 2012).

Di lain sisi, pemberitaan media dapat memiliki dampak positif pada masyarakat. Lawrence dan Mueller (2003) berpendapat bahwa media yang konstan mendidik dan mengingatkan individu tentang perilaku yang dapat diterima secara sosial di masyarakat. Oleh karena itu, "dengan menarik garis tegas antara apa yang dapat diterima dan apa yang menyimpang," media memperkuat norma sosial yang dipegang secara luas (Wing, 2012).

Sebaliknya, pengujian laporan media oleh Kupchik dan Bracy (2009) menggambarkan bahwa berita kejahatan yang berlebihan menghasilkan dampak sosial yang negatif. Kupchik dan Bracy (2009), serta Lawrence dan Mueller (2003), menemukan bahwa meskipun sekolah adalah salah satu tempat teraman bagi anak-anak, ketika disurvei, orang tua dan wali melaporkan bahwa mereka hampir merasa pasti insiden yang kejam akan terjadi di sekolah mereka dalam dua tahun ke depan. Mereka selanjutnya menemukan bahwa persepsi bahwa sekolah tidak aman berkorelasi positif dengan frekuensi laporan media tentang kekerasan di sekolah (Wing, 2012).

\section{Kepanikan Moral}

Teori kepanikan moral (moral panic) diperkenalkan oleh Stanley Cohen. Kepanikan moral menurut Cohen adalah reaksi masyarakat yang tidak proporsional terhadap tindakan orang, kelompok, yang dianggap menyimpang dari nilai dan norma sosial serta budaya yang berlaku. Para penjaga moral (tokoh masyarakat, agamawan, dan editor) bersatu padu dalam mendefinisikan 
suatu perilaku yang dianggap menyimpang. Dasar kepanikan moral adalah rasa terancam masyarakat yang terlalu dibesar-besarkan karena representasi tidak akurat suatu tindakan tertentu atau karena tindakan tersebut dianggap lebih serius daripada hal lain (Eriyanto, 2013).

Lima atribut kepanikan moral diperkenalkan Goode dan Ben-Yehuda untuk melengkapi model asli Cohen dengan menyediakan kerangka kerja yang komprehensif dari karakteristik yang melambangkan kepanikan moral. Indikator pertama, kekhawatiran, mewakili tingkat kecemasan yang meningkat tentang ancaman sosial yang dirasakan. Indikator kedua, perrmusuhan, dalam kepanikan moral sering dimanifestasikan melalui mentalitas "kita-versus-mereka". Indikator ketiga, konsensus terjadi ketika masyarakat setuju bahwa ancaman tertentu adalah "nyata, serius, dan disebabkan oleh kesalahan anggota kelompok dan perilaku mereka". Indikator keempat, tidak proporsional, yaitu ketika intensitas kepedulian publik melebihi ancaman aktual dari masalah sosial. Akhirnya indikator kelima, volatilitas terjadi sebagai hasil dari erupsi mendadak dan berkurangnya kepanikan moral, yang juga dapat disaksikan dalam jumlah perhatian yang diterima fenomena tertentu dalam wacana publik (Schildkraut et al, 2015)

Media memainkan peranan sangat penting dalam kepanikan moral. Ini terutama lewat kecenderungannya mendistorsi dan melebih-lebihkan peristiwa-peristiwa tertentu. Melalui headline yang sensasional, bombastis, kosa kata melodramatik dan sebagainya. Media secara aktif juga mengkonstruksi folk devils - pengacau masyarakat, yakni kelompok-kelompok yang mengancam nilai-nilai kemasyarakatan dan dianggap brutal serta berbahaya bagi "orang kebanyakan". Folk devils adalah istilah Cohen untuk menggambarkan kelompok, orang, pelaku yang menjadi "musuh media" karena dipandang membahayakan nilai-nilai moral masyarakat. Dalam konteks di Inggris misalnya: hooligans, punk, gangster, dan sebagainya. Di Indonesia misalnya: gay/lesbian, punk, hubungan tanpa nikah/ kumpul kebo (Eriyanto, 2013).

Asumsi pertama dari teori kepanikan moral adalah media massa dipandang sebagai sumber informasi yang diikuti masyarakat modern secara luas. Mayoritas masyarakat membaca koran, menonton televisi (berita) atau keduanya secara teratur, atau agak teratur. Asumsi kedua adalah bahwa karena kebanyakan orang tidak memiliki pengalaman langsung dengan kejahatan serius, sumber utama pemikiran dan perasaan publik mengenai kejahatan bersifat perwakilan (Sacco, 1982: 476). Asumsi kedua menunjukkan bahwa sebagian besar masyarakat bergantung pada media untuk informasi tentang kejahatan dan dalam hal ini berisiko mengambil pandangan yang terdistorsi (Gebotvs et al, 1988). Asumsi terakhir yang dikemukakan oleh Sacco (1982) adalah bahwa agenda media bisa jadi untuk mempromosikan liputan sensasional untuk meningkatkan tiras, menarik pemirsa, pengaruh politik atau ekonomi negara. Ini mungkin sangat jelas dalam periode ketika pembaca surat kabar diduga menurun (Bremmer, 1997).

Kepanikan moral adalah mekanisme bagi suatu komunitas untuk menjaga nilai-nilai bersama-seperti nilai kepantasan, moralitas, kesantunan, dan sebagainya. Jika ada suatu perilaku yang dipandang tidak sesuai dengan nilai-nilai yang hidup dalam masyarakat, masyarakat mempunyai mekanisme diri dalam menjaga nilai tersebut. Perilaku itu ditampilkan secara buruk dan menyimpang (deviance), sebagai 
akibatnya ada alasan untuk memberikan restriksi pada perilaku itu agar tidak berkembang. Media memainkan peranan penting dalam menciptakan kepanikan moral. Definisi mengenai perilaku menyimpang dan penggambaran buruk atas suatu perilaku yang dipandang menyimpang, dilakukan oleh media (Eriyanto, 2013).

\section{Peniru Kejahatan (Copycat Crime)}

Dalam pandangan Surette (2013) efek dari eksposure konten media yang mengandung model kriminal tidak terselesaikan dengan dua perspektif yang saat ini bersaing. Satu perspektif menganggap media menyediakan model kejahatan yang berfungsi sebagai penyebab langsung kejahatan atau sebagai pemicu kejahatan. Perspektif yang lain melihat model kejahatan di media berfungsi sebagai katalis pembentuk kejahatan atau sebagai kemudi kejahatan.

Model pertama diwakili oleh Model Agresi Umum atau General Agression Model (GAM) yang didukung oleh Anderson, Gentile dan Buckley (2007). Dalam model ini, eksposure konten media, terutama video game yang kejam, dianggap menyebabkan peningkatan perilaku agresif. Model Agresi Umum digambarkan sebagai pemodelan pasif di mana eksposure meningkatkan perilaku kekerasan terlepas dari kepribadian, lingkungan keluarga, genetika, atau kontribusi biologis (Ferguson, 2009). Dalam perspektif ini media berfungsi sebagai mekanisme pemicu di mana penghapusan eksposure konten media akan menghilangkan tindak pidana selanjutnya.

Sebaliknya dalam perspektif kedua, dimana media sebagai model katalis, individu yang dipidana secara kriminal didorong oleh motif yang sudah ada sebelumnya untuk melakukan kejahatan, kemudian mencari media untuk petunjuk melakukan kejahatan. Dalam model ini, konten media berfungsi sebagai katalisator kejahatan daripada pemicu terjadinya kejahatan. Kriminalitas dalam model katalis adalah proses bawaan berdasarkan kondisi biologis di mana temperamen dan kepribadian yang agresif serta faktorfaktor lingkungan yang tidak terkait dengan media, khususnya kekerasan keluarga, menghasilkan kekerasan dan kriminalitas. Eksposure media dalam model katalis dilihat memiliki peran kausal yang terbatas sampai nol. Sebaliknya, media berfungsi sebagai katalis gaya (Ferguson, Rueda, Cruz, Ferguson, Fritz, \& Smith 2008). Pada intinya, dalam model ini harapannya adalah bahwa tanpa eksposur media, kejahatan tidak dapat dihilangkan karena berbagai bentuk kejahatan masih akan dilakukan.

Ada kesulitan yang inheren dalam mempelajari peniru kejahatan karena sifatnya. Kesalahan mengidentifikasi peniru kejahatan dapat terjadi ketika peristiwa meniru kejahatan tidak dikenali dan tidak dilaporkan, karena pelaku kejahatan awal yang muncul di masa lalu atau kejahatan peniru yang terjadi di lokasi yang jauh. Selain itu, studi tentang kejahatan peniru terhalang oleh bahaya positif palsu di mana kejahatan memiliki kesamaan kejahatan sebelumnya terjadi secara tidak sengaja dihubungkan dan diberi label sebagai peniru kejahatan.

Ada beberapa contoh di mana media melabeli kejahatan yang disebabkan oleh eksposure konten media. Film Money Train misalnya didiskreditkan sebagai model untuk pembakaran/ perampokan/ pembunuhan petugas kereta bawah tanah New York (Cohen, 1999; Perez-Pena, 1995) dan peristiwa pembantaian dengan penembakan di University of Virginia Tech awalnya dikreditkan sebagai fotokopi film laga (Niza, 2007). Ada 


\section{Guntur Freddy Prisanto.}

juga kekhawatiran ketika para pelanggar secara retrospektif mengaitkan media sebagai sumber kriminalitas, walaupun kenyataannya pada saat terjadinya kejahatan tidak ada peran media. Pelaku mungkin tidak mengerti alasan melakukan kejahatan tertentu, atau mereka melakukan kejahatan karena alasan yang ingin mereka kaitkan media sebagai penyebab kriminalitas. Sebaliknya, ada juga kemungkinan bahwa pelaku tidak dapat menarik media sebagai sumber ide kejahatan mereka dan menghubungkannya dengan penemuan mereka sendiri. (Surette, 2013).

Banyak penelitian berfokus pada efek media terhadap perilaku manusia, tetapi hanya sedikit penelitian yang berfokus secara khusus pada peniru kejahatan. Surette (2002) meneliti peniru kejahatan yang dilaporkan sendiri pada pelaku remaja yang serius dan kejam di Florida. Ini adalah remaja yang mengidentifikasi diri sebagai peniru kejahatan. Surette menemukan bahwa "para remaja peniru kejahatan yang dilaporkan sendiri secara signifikan cenderung menganggap media sebagai pengaruh secara umum dan secara pribadi" (hlm. 63). Dia menyimpulkan dari penelitian ini bahwa "remaja yang cenderung mencari berbagai sumber informasi kejahatan adalah kandidat yang masuk akal untuk pengaruh kriminogen media" (hal. 63).

\section{Metode Penelitian}

Analisis naratif pada dasarnya adalah analisis mengenai cara dan struktur bercerita dari suatu teks. Analisis naratif melihat teks berita sebagai sebuah cerita. Narasi adalah bentuk teks yang paling tua dan paling dikenal, karena sesuai pengalaman hidup manusia. Teks berita kerap disajikan dalam bentuk narasi. Narasi tidak ada hubungannya dengan fakta dan fiksi, hanya berkaitan dengan cara bercerita, bagaimana fakta disajikan kepada khalayak. Dengan membuat dan menyajikan peristiwa dalam suatu narasi, maka sebuah peristiwa akan lebih mudah diikuti khalayak. Lewat analisis naratif, kita menempatkan berita tidak ubahnya seperti sebuah novel, puisi, cerpen, atau cerita rakyat. Di dalam teks berita terdapat jalan cerita, plot, karakter dan penokohan. Adapun yang membedakan, kalau novel fiksi cerita diambil dari fiksi, berita didasarkan pada peristiwa aktual (fakta). Novel mengangkat peristiwa secara dramatis dengan alur dan plot tertentu sehingga pembaca bisa membaca hingga selesai. Berita juga demikian. Penulisan berita juga diatur sedemikian rupa sehingga khalayak bisa mengikuti berita hingga tuntas. Teks dilihat sebagai rangkaian peristiwa, logika, dan tata urutan peristiwa, bagian dari peristiwa yang dipilih dan dibuang (Eriyanto, 2013).

Analisis naratif mempunyai sejumlah kelebihan. Pertama, membantu memahami bagaimana pengetahuan, makna, dan nilai diproduksi dan disebarkan dalam masyarakat. Kedua, memahami bagaimana dunia sosial dan politik diceritakan dalam pandangan tertentu yang dapat membantu kita mengetahui kekuatan dan nilai sosial yang dominan dalam masyarakat. Banyak cerita (seperti narasi sejarah) lebih merepresentasikan kekuatan dominan, kelompok berkuasa yang ada dalam masyarakat. Ketiga, analisis naratif memungkinkan kita menyelidiki hal-hal yang tersembunyi dan laten dari suatu teks media. Peristiwa disajikan dalam bentuk cerita, dan dalam cerita tersebut sebenarnya terdapat nilai-nilai dan ideologi yang ingin ditonjolkan oleh pembuat berita. Analisis naratif membantu kita mengerti keberpihakan dan ideologi dari pembuat berita. Keempat, analisis naratif merefleksikan 
kontinuitas dan perubahan komunikasi. Cerita yang sama mungkin diceritakan beberapa kali dengan cara dan narasi yang berbeda dari satu waktu ke waktu lain. Lewat analisis naratif kita bisa menganalisis perubahan narasi sebagai bentuk dari perubahan nilai-nilai yang ada dalam masyarakat (Eriyanto, 2013).

\section{Hasil Penelitian dan Pembahasan}

Sekitar 7 minggu dari sejak pertama kali tertangkapnya artis VA, apabila kita menjelajah situs pencari google.com dan memasukkan kata kunci pencarian "prostitusi online $\mathrm{V}^{* * * * * * *}$ A****”, maka akan ditemukan kurang lebih 2.880.000 entry pemberitaan (per 23 Februari 2019). Ini pemberitaan yang sangat fenomenal, apabila dibandingkan dengan berbagai pemberitaan di lingkup nasional. Bandingkan dengan beberapa topik berita berlingkup nasional lainnya:

Kata kunci "penanganan bencana Palu"(peristiwa 2 Oktober 2018) ditemukan kurang lebih 1.700 .00 entry,

Kata kunci "penanganan tsunami Banten dan Lampung" (peristiwa 23 Desember 2018) ditemukan kurang lebih 395.000 entry,

Kata kunci "Jokowi resmikan tol Trans Jawa" (peristiwa 20 Desember 2018) ditemukan kurang lebih 390.000 entry.

Pemberitaan atas kasus VA ini meliputi berbagai aspek. Ada yang memuat kisah persahabatan VA dengan seorang artis (JS), yang justru dimulai dengan perseteruan akibat VA hadir sebagai orang ketiga dalam hubungan asmara JS dengan seorang laki-laki (brilio.net, 9 Januari 2019). Pemberitaan berlanjut tentang mundurnya tim pengacara Vanessa Angel (nasional.tempo.co, 10 Januari 2019), motif keterlibatan VA dalam prostitusi online karena terlilit utang (kapanlagi.com, 21 Januari 2019), tidak harmonisnya hubungan VA dan ayahnya (wartakota.tribunnews.com, 25 Januari 2019 dan youtube channel tribunnews.com, tanpa tanggal), saling sindir pacar VA dan artis JS lewat media sosial (m.kapanlagi.com, 30 Januari 2019), hingga komentar seorang pengamat dunia hiburan yang mengkategorikan tarif VA sebesar Rp. 80 juta masuk dalam kelas menengah, karena masih banyak yang lebih mahal (bali.tribunnews.com, 7 Februari 2019), protes pengacara VA karena pria yang tertangkap bersama VA tidak jelas proses hukumnya (banjarmasin.tribunnews.com, 21 Februari 2019).

Dilihat dari kuantitas berita dan luas cakupan pemberitaan, dapat dikatakan bahwa pemberitaan prostitusi online VA dapat dikatakan berlebihan. Media mengeksploitasi nilai sensasional dari pemberitaan ini. Penyajiannya pun disajikan sebagai drama kehidupan seorang artis. Nama artis VA sendiri sebetulnya sudah lama tidak muncul, terakhir kali namanya muncul ketika ia terlibat perseteruan dan adu mulut dengan seorang artis lain (JS), karena VA hadir di tengah hubungan artis JS dengan seorang laki-laki. Ketika media massa mengangkat berita tertangkapnya VA di sebuah hotel, maka yang lebih menarik perhatian sebetulnya adalah perilakunya, prostitusi artis, dibandingkan nama sang artis itu sendiri.

Prostitusi artis sendiri adalah sebuah fenomena yang sempat menghangat, ketika seorang artis terkenal NM disebut tertangkap basah di hotel Kempinski Jakarta pada akhir tahun 2015. Setelah itu topik ini menjadi pembicaraan pada tingkat rumor dan bisik-bisik belaka. Topik ini biasanya menyertai sorotan tentang kehidupan seorang artis yang tidak terlihat secara jelas karyanya ataupun penampilannya di depan publik, namun menunjukkan gaya hidup yang mewah. Tidak ada 
pemberitaan yang sifatnya menyeluruh dan investigatif. Berbeda dengan pemakaian narkoba atau perselingkuhan di kalangan artis yang lebih banyak menjadi pemberitaan terbuka di media massa.

Pemberitaan soal prostitusi online artis VA, bisa dikatakan sebagai babak baru dalam kisah prostitusi. Ia tak lagi sebagai mekanisme transaksi yang sangat tertutup dan beredar di kalangan sangat terbatas. Karena dalam kasus prostitusi online yang terjadi pada VA, ada "alat peraga" berupa foto mesum dan video mesum singkat VA yang disebarkan secara online. Penyebaran materi ini yang kemudian menjerat VA secara hukum.

Nilai sensasi yang tinggi dari pemberitaan kasus ini, menyebabkan media massa membanjiri audiens dengan tema ini. Mengalahkan prioritas atas pemberitaan peristiwa-peristiwa lain yang berskala nasional. Media online jelas lebih leluasa, karena tidak dibatasi oleh ruang dan waktu sebagaimana pada media cetak. Mereka juga dapat mengupdate pemberitaan kapan saja, walaupun kerap kali dari update sebuah berita yang benar-benar bernilai kebaruan hanyalah 2-3 paragraf awal. Sementara paragraf-paragraf berikutnya hanyalah pengulangan dari pemberitaanpemberitaan sebelumnya. Kerap kali pemberitaan di media online menjadikan judul sebagai daya tarik utama untuk pembaca. Judul dibuat sedemikian sensasional dan bombastis agar menjadi clickbait.

Banjir informasi dari media massa, juga tak lepas dari animo masyarakat atas kasus ini. Readership yang tinggi mendorong media massa untuk lebih berfokus atas tema tertentu. Keterlibatan audiens pada tema ini juga dapat dirasakan dengan munculnya berbagai produk kreatif yang menyajikan satire dalam bentuk meme, stiker untuk berkomunikasi melalai whatsapp maupun video lagu pendek yang isinya sindiran dan olok-olok pada fenomena prostitusi artis.

Bagi sebagian kelompok masyarakat pemberitaan soal prostitusi artis menjadi pengalihan atas kelelahan dalam menghadapi berbagai isu sosial politik yang menghangat menjelang Pemilu April 2019. Ada juga yang menjadikannya sebagai ajang pertarungan ide menentang dominasi patriarkhi, mengingat dalam peristiwa ini yang terlihat dipersoalkan hanya artis VA, seorang perempuan. Sementara laki-laki yang ditangkap bersamanya, seorang pengusaha tambang, tidak pernah diekspose di media massa. Ada juga yang menganalisis peristiwa ini sebagai sebuah pertunjukan ketimpangan sosial yang telanjang. Tarif artis VA sekali kencan kurang lebih sama dengan upah buruh di Karawang (salah satu yang tertinggi di Indonesia) selama 19 bulan kerja (Upah Minimum Kabupaten Rp. 4.234.010).

Bergulirnya pemberitaan kasus prostitusi online VA ini berperan penting menciptakan kepanikan moral. Media tidak menjadikan pemberitaan atas kasus ini sebagai sebuah pemberitaan yang bersifat deskriptif dan menceritakan sebuah peristiwa belaka. Dengan mengorek berbagai aspek kehidupan VA, media massa menjadikan VA sebagai tokoh dalam sebuah narasi, yang perlu diikuti cerita hidupnya dalam sebuah plot yang bergerak ke sana ke mari.

Ditinjau dari narasi pemberitaan, VA sebagai seorang pelaku tindak asusila dalam jalan cerita yang disajikan media massa, tidak serta merta menjadi tokoh antagonis. Dalam kaitannya dengan laki-laki pengusaha tambang yang tertangkap bersamanya, VA diposisikan sebagai korban ketidakadilan. Nama, wajah dan 
kehidupan pribadinya dikupas tuntas, sementara sang laki-laki aman dalam anonimitas. Hanya sempat beredar nama dan profesinya; bukan foto wajah, kehidupan pribadi dan sebagainya. Dalam relasinya dengan artis JS, maka VA menjadi korban dalam bentuk lain. VA seolah hanya menjadi pijakan untuk ketenaran artis JS, yang pada saat sama sedang mencalonkan diri menjadi anggota legislatif. Bentuk pertolongan JS pada VA diselimuti tafsir bahwa itu tak lebih upaya untuk mendapat liputan media. Sementara dalam relasinya dengan ayahnya, VA menjadi korban ketidakpedulian keluarga. Sehingga keseluruhan jalan cerita kasus VA ini, menjadi bukan semata-mata hubungan seksual yang didasari transaksi, namun terjalin dalam plot yang sedemikian kompleks.

Dalam salah satu pemberitaan tentang hubungannya dengan sang Ayah, dijelaskan bagaimana perbedaan karakter yang menyolok antara Ayah dan VA. Sosok Ayah yang rapih, bersih, disiplin dan teratur menjadi salah satu dasar ketidakcocokan dengan VA. Upaya Ayah untuk mendisiplinkan, justru membuat VA tidak nyaman dan kerap menimbulkan pertengkaran. Akhirnya ini yang mendorong VA untuk meninggalkan rumah sejak usia 16 tahun bersama pria pilihannya (wartakota.tribunnews.com, 24 Januari 2019). Relasi ayah dan anak yang tidak harmonis ini, terbawa bahkan ketika VA terlibat kasus prostitusi online. Pada media massa, VA menyatakan bahwa ketika mendapati kesulitan seperti ini, keluarganya tidak memberikan dukungan padanya (kumparan.com, 26 Januari 2019).

Jalinan cerita yang disajikan dengan begitu rinci mencakup berbagai aspek, dapat membawa audiens pada penilaian yang tidak final pada sosok VA. Audiens tidak akan melihatnya semata persoalan benar atau salah, pada titik tertentu muncul empati dan sikap memaklumi. Hal ini juga dapat dilihat dari beberapa artikel yang memberikan pembelaan atas pilihan hidup VA.

Penyajian kisah VA secara narasi dalam pemberitaan, menjaga audiens untuk tetap mengikuti perkembangan terbaru. Pelaporannya yang intensif secara tidak sadar telah membangun kepanikan moral yang berfokus pada prostitusi online. Indikator pertama dari kepanikan moral, yaitu kekhawatiran, muncul dalam bentuk tingkat kecemasan yang meningkat tentang ancaman sosial yang dirasakan. Ancaman sosial yang muncul adalah betapa mudahnya melakukan transaksi asusila. Pertukaran informasi nama artis, tarif disertai alat peraga foto dan video mesum begitu mudah dipertukarkan melalui platform komunikasi yang dipergunakan masyarakat secara luas, yaitu whatsapp.

Indikator kedua, permusuhan, dalam kepanikan moral sering dimanifestasikan melalui mentalitas "kita-versus-mereka". Permusuhan yang meningkat dapat mengarah pada kelompok yang menyimpang atau di luar grup dengan perilakunya yang bermasalah. Karena hubungan seksual berbasis transaksi melibatkan sedikitnya dua pihak, maka kelompok yang dianggap menyimpang dalam kasus ini seharusnya mewakili kedua pihak tersebut. Namun karena pemberitaan sejauh ini lebih berfokus pada VA, maka permusuhan yang dirasakan masyarakat lebih mengarah pada kelompok yang direpresentasikan VA, artis maupun model yang juga menawarkan jasa prostitusi online.

Indikator ketiga, konsensus terjadi ketika masyarakat setuju bahwa ancaman tertentu adalah "nyata, serius, dan disebabkan oleh kesalahan anggota kelompok dan perilaku mereka". Prostitusi online dirasakan sebagai ancaman nyata, serius dan disebabkan kesalahan anggota kelompok dapat 
muncul ketika pemberitaan ini berlanjut, dan ternyata mengindikasikan keterlibatan puluhan nama yang juga dari profesi artis, selebgram, mantan finalis kontes kecantikan dan lain-lain. Ini dapat mendorong konsensus, bahwa profesi tertentu rentan pada keterlibatan tindak asusila prostitusi online.

Indikator keempat, tidak proporsional, yaitu ketika intensitas kepedulian publik melebihi ancaman aktual dari masalah sosial. Konsep kepanikan moral secara inheren bersifat subyektif, karena tidak semua orang menganut ide yang sama tentang fenomena tertentu. Kunci untuk memahami bagaimana kepanikan moral adalah ketidakseimbangan. Kepanikan moral tentang suatu peristiwa menunjukkan tingkat disproporsionalitas yang tinggi antara jumlah perhatian yang didapat dan frekuensi terjadinya peristiwa tersebut. Kasus prostitusi online yang melibatkan artis dan selebritis, baru kembali merebak, setelah sebelumnya terjadi pada akhir tahun 2015. Terhitung sangat jarang terjadi. Namun keluasan eksposure dan intensitas pemberitaan menunjukkan tingginya perhatian atas peristiwa ini.

Akhirnya indikator kelima, volatilitas terjadi sebagai hasil dari erupsi mendadak dan berkurangnya kepanikan moral, yang juga dapat disaksikan dalam jumlah perhatian yang diterima fenomena tertentu dalam wacana publik. Volatilitas mengacu pada letusan tiba-tiba dari fenomena kepanikan moral, yang juga dapat mereda dengan tiba-tiba. Salah satu cara untuk menguji volatilitas adalah dengan mempertimbangkan lamanya waktu dimana perhatian publik difokuskan pada masalah tertentu. Hampir dua bulan sejak pertama kali masalah prostitusi online VA ini mengemuka, media masih mengangkat persoalan ini. Fokusnya memang sedikit bergeser dari VA ke beberapa nama lain yang diselidiki kepolisian.

Sebagai sebuah tindakan asusila yang modus operandinya relatif sederhana, prostitusi online menimbulkan kekhawatiran tersendiri yaitu mudahnya ditiru. Dengan mengadopsi model copycat crime yang diteliti oleh Surette (2013), prostitusi online dapat memunculkan penirupeniru pelaku tindak asusila sebagai dampak eksposure konten media. Bahkan kedua perspektif baik yang menganggap media menyediakan model kejahatan yang berfungsi sebagai penyebab langsung, maupun yang memandang media berfungsi sebagai mekanisme pemicu/ katalis pembentuk kejahatan; dapat berlaku pada prostitusi online.

Dalam perspektif pertama, maka siapa pun yang terkspose konten media prostitusi online VA, dapat terpicu untuk melakukan hal yang sama. Ini didukung dengan mudahnya pola tindak asusila ini dijalankan. Penawaran prostitusi online secara terselubung ditengarai dapat ditemukan pada beberapa platform media sosial seperti twitter dan instagram. Maka betapa mudahnya bagi mereka yang berniat melakukan hal yang sama untuk menirunya.

Sementara untuk perspektif kedua, yang memandang media berfungsi sebagai mekanisme pemicu/ katalis pembentuk kejahatan, dapat menjadikan konten pemberitaan prostitusi online VA sebagai pemicu untuk melakukan hal yang sama. Ini dapat terjadi pada mereka yang mempunyai pola pikir cenderung permisif pada seks bebas atau telah terlibat dengan bentuk lain dari prostitusi, sehingga menjadikan prostitusi online sebagai modus baru tindak asusila, dibandingkan yang biasa dilakukan. 
Kekhawatiran paling besar adalah apabila yang berkeinginan untuk meniru adalah audiens dari kelompok usia remaja. Gaya hidup masyarakat modern yang semakin terbuka dan permisif dalam hubungan antar jenis, ditambah perilaku konsumtif; akan memperbesar peluang ditirunya tindak asusila yang diberitakan secara berlebihan di media massa. Karena itu proporsionalitas dalam kuantitas maupun keluasan pembahasan dari suatu peristiwa atau pelaku tindak asusila, harus menjadi perhatian serius bagi pengelola media massa.

\section{Simpulan}

Semua indikasi yang merupakan atribut kepanikan moral, menunjukkan bahwa pemberitaan media massa dengan kuantitas yang tinggi dan luasnya cakupan terkait subyek berita VA, menjadikannya sebagai dasar munculnya kepanikan moral. Hal ini diamplifikasi dengan gaya pelaporan dalam pemberitaan seperti narasi, yang menjadikan VA sabagai tokoh utama, yang tidak serta merta antagonis, namun diselimuti keberadaan tokoh-tokoh lain yang menjalin plot cerita yang lebih kompleks.

Pemberitaan tindak asusila yang berlebihan dapat menyebabkan timbulnya kecenderungan meniru perilaku yang sama. Pada perspektif kecenderungan meniru tindak asusila dimana konten media berfungsi sebagai penyebab langsung, maka pembatasan pemberitaan tindak asusila akan mengurangi peluang ditirunya perilaku oleh audiens dengan karakter sama seperti pada tokoh dalam berita.

\section{Daftar Pustaka}

Jurnal dan Buku:

Birch, Danae L., The Media Made Me

Do It: An Examination of Media
Copycats, Tesis, The Department of Communication and Journalism and The Graduate School of The University of Wyoming, 2005

Bremner, Melanie Anne, Youth and Youth Crime: A Moral Panic; A Content Analysis of Four Ontario Newspaper, Tesis pada The Faculty of Graduate Studies of The University of Guelph, 1997

Eriyanto, Analisis Naratif: Dasar-dasar dan Penerapannya dalam Analisis Teks Berita Media, Jakarta: Kencana Prenada Media Group, 2013

Kupchik, Aaron and Nicole L. Bracy, The New Media on School Crime and Violence: Constructing Dangerousness and Fueling fear, Youth Violence and Juvenile Justice (2009), 7 (136-155).

Lawrence, Richard and D. Mueller, School Shootings and the ManBites-Dog Criterion of Newsworthiness, Youth Violence and Juvenile Justice (2003), 1(330-345).

Schildkraut, Jaclyn \& H. Jaymi Elsass \& Mark C. Stafford, Could it Happen Here? Moral Panic, School Shootings, and Fear of Crime among College Students, Crime Law Soc Change (2015) 63:91-110

Surette, Ray, Cause or Catalyst: The Interaction of Real World and Media Crime Models, AmJ Crim Just (2013) 38:392-409

Surette, Ray, Self-reported Copycat Crime among a Population of Serious and Violent Juvenille Offenders, Crime \& Delinquency (2002), 48 (1), 46 - 66

Wing, Jonathan A., If It Bleeds It Leads: The Correlation Between The Consumption of Crime News Media and The Public's Fear of 
Violent Crime, Tesis, University of New Hampshire, 2012

Berita:

Soal Prostitusi Online di Surabaya, Pengacara Sebut Vanessa Angel Dijebak, detik.com didownload 11 Februari 2019.

Moammar Emka: Tarif Prostitusi Online Seperti Vanessa Angel Murah, Kelas Atas Fasilitasnya Begini, www.bali.tribunnews.com, didownload 11 Februari 2019.

Vanessa Angel Ditahan Polda Jatim, Sembunyikan Sesuatu di Balik Baju Tahanan hingga Alami Insiden, jatim.tribunnews.com, didownload 11 Februari 2019.

Lika-liku Persahabatan Jane Shalimar dan Vanessa Angel, www.brilio.net, didownload 11 Februari 2019.

Tim Pengacara Vanessa Angel Kompak Menyatakan Mundur, nasional.tempo.co, didownload 11 Februari 2019.

Hubungan Vanessa Angel dan Ayahnya Tidak Harmonis Selama Hidup, wartakota.tribunnews.com, didownload 11 Februari 2019.

Disindir Pacar Vanessa Angel, Jane Shalimar Balas Lewat Instagram, www.kapanlagi.com, didownload 11 Februari 2019.

Vanessa Angel Tinggalkan Ayahnya Karena Dilarang Pacaran dengan Lelaki Ini, www.youtube.com, didownload 11 Februari 2019.

Konflik Panas Vanessa Angel dan Ayahnya Usai Terseret Kasus Prostitusi, www.kumparan.com, didownload 11 Februari 2019. 